\title{
Penerapan Model Inkuiri Apresiatif Bagja Untuk Melatih Berpikir Kreatif
}

\author{
Widia $^{1}$, Adi Dermawansyah ${ }^{2}$, Yusuf $^{3}$, Fitria Sarnita $^{4 *}$ \\ ${ }^{12}$ STKIP Harapan Bima \\ ${ }^{3}$ SMAN 1 Ambalawi \\ ${ }^{4}$ STKIP Taman Siswa Bima \\ Email: fitriasarnita21@gmail.com ${ }^{4 *}$
}

\begin{abstract}
This research is a research application of the Appreciative Inquiry-BAGJA model to train students' creative thinking. The data collection method uses purposive sampling because it has a specific purpose, namely to train students' creative thinking. This research was conducted on second-semester students of the science education study program with 10 students as research subjects. The results of the data analysis of the students' creative thinking test results were obtained in the initial test of $45 \%$ in the less creative category and $75 \%$ in the creative category. While the results of the analysis of student responses to the process of using the BAGJA appreciative inquiry, it was obtained that the average number of students who responded positively was $90 \%$. By applying the BAGJA inquiry model, it can train students' creative thinking.
\end{abstract}

Keywords: Inquiry-BAGJA \& Creative Thinking

\section{Abstrak}

Penelitian ini adalah penelitian penerapan model Inkuiri Apresiatif-BAGJA untuk melatih berpikir kreatif mahasiswa. Metode pengumpulan data menggunakan purposive sampling karena memiliki tujuan khusus yaitu ingin melatih berpikir kreatif mahasiswa. Penelitian ini dilaksanakan pada mahasiswa semester II program studi pendidikan IPA dengan subyek penelitian 10 mahasiswa. Hasil analisis data hasil tes berpikir kreatif mahasiswa di dapatkan pada tes awal $45 \%$ dengan kategori kurang kreatif dan 75\% dengan kategori kreatif. Sedangkan hasil analisis respon mahasiswa terhadap proses menggukan inkuiri apresiatif BAGJA diperoleh rata-rata mahasiswa yang merespon positif 90\%. Secara pnerapan model inkuiri BAGJA dapat melatih berpikir kreatif mahasiswa.

Kata Kunci: Inkuiri-BAGJA \& Berpikir Kreatif

\section{PENDAHULUAN}

Tujuan terbesar berdirinya suatu lembaga pendidikan adalah untuk mencerdaskan anak Bangsa, mengasah keterampilan dan menjadikan insan Indonesia yang berakhlak mulia (Satriawan, M., Murtalib., 2018). Pendidikan diartikan sebagai 'tuntunan dalam hidup tumbuhnya anak-anak (Kemdikbud, 2020). Namun fakta berbicara lain, dengan kondisi geografis yang terbentang luas, Transformasi pendidikan yang dicita-citakan bersama berlum merata di Indonesia, termasuk di daearah Bima Nusa Tenggara Barat. Bima belum sepenuhnya menerapkan pendidikan yang berorientasi pada peserta didik, pembelajaran yang menyenangkan dan memberi ruang peserta didik untuk mengekspresikan dirinya, melatih kreativitas atau menemukan hal baru melalui percobaan. Hasil penelitian dosen dan mahasiswa tahun 2019, proses pembelajaran dikelas masih konfensional, sehingga membuat siswa kurang aktif dalam mengikuti pembelajaran dan sulit memahami materi yang diajarkan sehingga pembelajaran menjadi kurang bermakna (Dahlia et al., 2017). Berdasarkan hasil wawancara dengan mahasiswa tentang pengalaman belajar di SMA, serta observasi lapangan saat mahasiswa PPL, rata-rata mereka memberikan respon bahwa:

1) Pembelajaran berpusat pada guru, dimana guru sangat berperan aktif dalam menyampaikan materi.

2) Pembelajaran hanya mengacu pada teks (buku) tidak bervariatif

3) Pembelajaran bersifat menoton/kaku dan bersifat abstrak.

Jika masalah ini terus dibiarkan dan terusmenerus seperti itu, maka bisa dipastikan bahwa pendidikan Indonesia akan semakin jauh tertinggal dari Negara lain, khususnya tidak ada lagi siswa yang beminat untuk belajar IPA. Pada hal IPA/Sains sangat berperan penting dalam kehidupan kita, karena didalamnya membahas tetang seluruh elemen yang ada dilingkungan sekitar kita; seperti ekosistem, tumbuhan dan hewan, siklus air, partikel, zat, unsur dan 
senyawa, serta benda-benda langit dan keterkaitannya dengan perubahan iklim, cuaca dan fenomena alam yang terjadi.

Maka untuk mengatasi itu semua, Penulis ingin merancang sebuah pembelajaran yang berpihak kepada peserta didik, memberkan ruang kepada peserta didik untuk menemukan dan melatih memecahkan masalah secara otentik. Tujuan Penulis memilih Mahasiswa sebagai subyek penelitian adalah mempersiapkan calon pendidik yang kreatif dan inovatif yang nantinya ketika menyadi Guru dapat metranformasikan pendidikan yang memerdekakan bagi peserta didiknya. Maka keterampilan berpikir kreatif harus dilatih sedini mungkin (Fitria Sarnita et al., 2019). Karena mahasiswa Pendidikan IPA sebagai calon Guru IPA untuk masa yang akan datang, bagus dan tidaknya wajah pendidikan Indonesia di masa yang akan datang bergantung pada bagaimana kita mepersiapkan calon guru hari ini. Oleh karena itu, hendaknya sedini mungkin untuk dipembelajarkan kepada mahasiswa pembelajaran yang kontektual, bermakna dan berbasis masalah yaitu dengan desain perangkat pembeajaran model Inkuri Apresiatif-BAGJA sebagai solusi yang tepat untuk melatih keterampilan berpikir mahasiswa.

Berpikir kreatif berarti memandang sesuatu dari berbagai macam sudut pandang yang berbeda dengan berbagai kemungkinan yang ada (Satriawan et al., 2020). Artinya seorang dituntut untuk memiliki banyak alternatif dalam memutuskan sesuatu, memiliki kepekaan yang tinggi dan berpikir spontan. Peserta didik memiliki kemampuan untuk mengembangkan, melaksanakan, dan menyampaikan gagasan-gagasan baru secara logis, bersikap terbuka, dan responsif terhadap perspektif baru yang diterimanya (Rachmawati et al., 2018). Sehingga mahasiswa sebagai calon Guru masa depan mampu memenui tuntutan Abad ke -12, memiliki kemampuan untuk membangun dan mendesain pembelajaran yang berpihak kepada siswa, menumbuh kembangkan minat dan motivasi belajar mereka.

Ada empat indikator keterampilan berpikir kreatif, yaitu: fluency, flexibility, originality \& elaboration (Lestari et al., 2018) Kelancaran (fluency) adalah suatu kemampuan untuk menghasilkan banyak ide; fleksibilitas (flexibility) adalah suatu kemampuan dalam menghasilkan ideide yang lebih bervariasi; orisinalitas (originality) merupakan kemampuan menghasilkan ide baru atau ide yang sebelumnya tidak ada; dan elaborasi (elaboration) adalah suatu kemampuan untuk mengembangkan ide sehingga dihasilkan ide yang rinci dan detail.

\section{METODE}

Penelitian ini dilaksanakan pada mahasiswa semester genap tahun akademik 2020-2021 sebanyak 10 orang. Mahasiswa tersebut dijadikan sampel penelitian menggunakan purposive sampling atau berbasis tujuan. Soal yang digunakan untuk melati berpikir kreatif mahasiswa adalah soal open ended sebanyak 5 nomor esay.

\section{HASIL DAN PEMBAHASAN}

Hasil analisis peningkatan keterampilan berpikir kreatif rata-rata seluruh mahasiswa setelah mengikuti pembelajaran selama tiga pertemuan pada aspek berpikir kreatif sebelum perlakuan sebesar $45 \%$ dengan kategori kurang kreatif. Sedangkan setelah diberikan perlakuan meningkat menjadi $75 \%$ dengan kategori kreatif

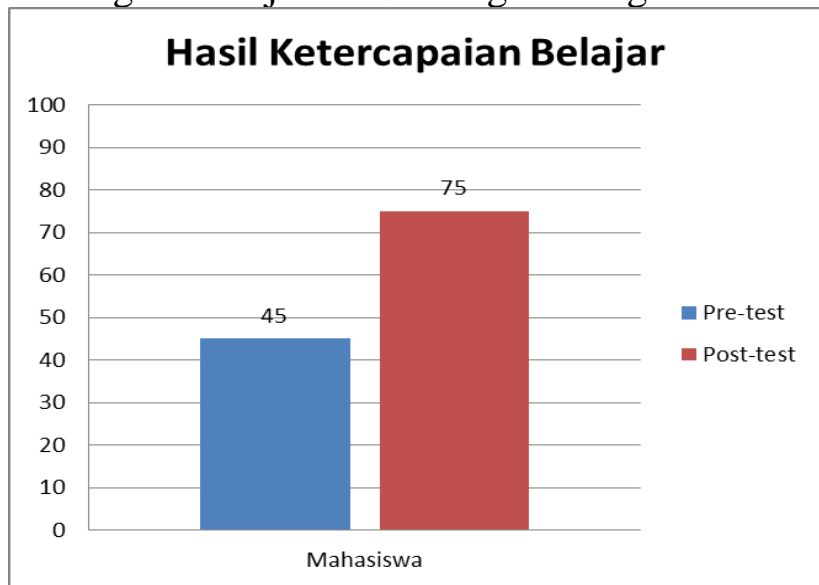

Gambar 1. Peningkatan Hasil Tes Berpikir Kreatif Mahasiswa

Hal ini terjadi karena selama proses pembelajaran mahasiswa diarahkan dengan pertanyaan terbuka, yang mampu membuat mahasiswa untuk berpikir dalam menyelesaikan masalah yang ada. Sesuai dengan alur BAGJA (Buat pertanyaan, Ambil pelajaran, Gali mimpi dan Jabarkan Aksi) dengan tahapan 
pembelajaran tersebut mahasiswa merasa dilibatkan dan diperhatikan oleh dosennya.

Menciptakan suasanya belajar yang nyaman dan menyenangkan adalah suatu keharusan bagi pengajar. Menyenangkan diartikan sebagai suasana belajar yang hidup, semarak, terkondisi untuk berlanjut, dan ekspresif. Hal ini didukung oleh hasil penelitian tentang Penggunaan Lembar Kerja (LKS) Berbasis STEM Untuk Melatih Keterampilan Berpikir Kreatif Siswa Tuna Netra (Sarnita et al., 2019). Serta Hasil penelitian Satriawan at al., (2017). Pengembangan Perangkat Pembelajaran Fisika Berbasis Karakter Maja labo Dahu untuk Melatih Keterampilan Berpikir Kreatif Siswa. Oleh karena itu kegiatan belajar yang aktif, kreatif dan menyenangkan harus tetap bersandar pada tujuan atau kompetensi yang hendak dicapai (Widia et al., 2021). Efektif yang diartikan sebagai ketercapaian suatu tujuan merupakan pijakan utama suatu rancangan pembelajaran.

Selain mampu melatih berpikir kreatif, model inkuiri apresiatif-Bagja dapat memotivasi belajar mahasiswa, dimana 90\% mahasiswa sangat antusias dan meminta untuk menggunakan model yang sama pada pembelajaran yang lain juga.

\section{KESIMPULAN}

Secara keseluruhan penerapan model inkuiri BAGJA dapat melatih berpikir kreatif mahasiswa prodi IPA semester II karena mereka merasa dilibatkan dalam setiap tahap pembelajaran tersebut, melibatkan masalalu mereka untuk meraih cita-cita mereka yang lebih baik dimasa depan.

\section{SARAN}

Semoga pembaca dan peneliti selanjutnya dapat melengkapi kekurangan yang ada pada penelitian ini, teurtama yang berkaitan dengan hubungan berpikir kreatif dan hasil belajar mahasiswa.

\section{UCAPAN TERIMA KASIH}

Ucapan terima kasih kami sampaikan kepada: PPK Direktorat Sumber Daya, Direktur Jenderal Pendidikan Tinggi, Riset dan Teknologi, Kemdikbud. nomor kontrak :
069/E4.1/AK.04.PT/2021 yang telah membantu mendanai penelitian ini $100 \%$. Ketua STKIP Harapan Bima yang telah mengizinkan kami melakukan penelitian.

\section{DAFTAR PUSTAKA}

Dahlia, D., Panjaitan, R. L., \& Djuanda, D. (2017). Penerapan Model Pembelaaran Inkuiri Pada Materi Sifat-Sifat Benda untuk Meningkatkan Hasil Belajar Siswa Kelas IV. Jurnal Pena Ilmiah, 2(1), 391-400.

Kemdikbud. (2020). Refleksi Filosofi Pendidikan Nasional: Ki Hadjar Dewantara. Tidak dipublikasikan. Jakarta. Tim Penyusun Modul PGP

Lestari, T., Nyeneng, I. D. P., \& Herlina, K. (2018). Membangun Keterampilan Berpikir Kreatif Siswa Melalui LKPD Berbasis Scientific Approach Materi Elastisitas dan Hukum Hooke: Penelitian Pendahuluan. Jurnal Pembelajaran Fisika, 6(2).198-208.

Rachmawati, F., Kirana, T., \& Widodo, W. (2018). Buku Ajar Interactive Book untuk Meningkatkan Kemampuan Berpikir Kreatif Siswa Sekolah Dasar. Jurnal Penelitian Pendidikan IPA, 2(1), 19-29.

Sarnita, F., \& Fitriani, A. (2019). Pengembangan Perangkat Pembelajaran Model PBL Berbasis STEM untuk Melatih Keterampilan Berfikir Kreatif Siswa Tuna Netra. Jurnal Pendidikan MIPA, 9(1), 38-44.

Satriawan, M., Murtalib \& Widia. (2017). Pengembangan Perangkat Pembelajaran Fisika Model Problem Based Learning (PBL) Berbasis Karakter Maja labo Dahu untuk Melatih Keterampilan Berpikir Kreatif Siswa. Gravity Edu: Jurnal Pembelajaran dan Pengajaran Fisika. 1 (2), 20-24.

Satriawan, M., Rosmiati, R., Widia, W., Sarnita, F., Suswati, L., Subhan, M., \& Fatimah, F. (2020). Physics learning based contextual problems to enhance students' creative thinking skills in fluid topic. In Journal of Physics: 
Conference Series (Vol. 1521, p. 022036).

Widia, Sarnita, F., Irawan, A., Syafrudin, A., Hunaepi, N., Sapnowandi, S., \& Asy'ari, M. (1816). The effectiveness of guided inquiry learning tools in increasing students' activities and creative thinking skills. In Journal of Physics: Conference Series (Vol. 2021, p. 012102). 